\title{
Expression of fatty acid sensing G-protein coupled receptors in peripartal Holstein cows
}

\author{
Alea Agrawal, Abdulrahman Alharthi, Mario Vailati-Riboni, Zheng Zhou and Juan J. Loor
}

\begin{abstract}
Background: G-protein coupled receptors (GPCR), also referred as Free Fatty Acid Receptors (FFAR), are widely studied within human medicine as drug targets for metabolic disorders. To combat metabolic disorders prevalent in dairy cows during the transition period, which co-occur with negative energy balance and changes to lipid and glucose metabolism, it may be helpful to identify locations and roles of FFAR and other members of the GPCR family in bovine tissues.

Results: Quantitative RT-PCR (qPCR) of subcutaneous adipose, liver, and PMNL samples during the transition period $(-10,+7$, and +20 or +30 d) were used for expression profiling of medium- (MCFA) and long-chain fatty acid (LCFA) receptors GPR120 and GPR40, MCFA receptor GPR84, and niacin receptor HCAR2/3. Adipose samples were obtained from cows with either high ( $H$; $B C S \geq 3.75)$ or low (LO; BCS $\leq 3.25)$ body condition score $(B C S)$ to examine whether FFAR expression is correlated with this indicator of health and body reserves. Supplementation of rumen-protected methionine (MET), which may improve immune function and production postpartum, was also compared with unsupplemented control (CON) cows for liver and blood polymorphonuclear leukocytes (PMNL) samples. In adipose tissue, GPR84 and GPR120 were differentially expressed over time, while GPR40 was not expressed; in PMNL, GPR40 was differentially expressed over time and between MET vs. CON, GPR84 expression differed only between dietary groups, and GPR120 was not expressed; in liver, GPCR were either not expressed or barely detectable.
\end{abstract}

Conclusions: The data indicate that there is likely not a direct role in liver for the selected GPCR during the transition period, but they do play variable roles in adipose and PMN. In future, these receptors may prove useful targets and/or markers for peripartal metabolism and immunity.

Keywords: Inflammation, Methionine, Neutrophils, Transition cow

\section{Background}

The G-protein coupled receptor (GPCR) superfamily is one of the largest families of receptor proteins, comprising $1 \%$ or more of the human genome, and as much as $5 \%$ in simpler organisms like the nematode $[1,2]$. GPCR are also termed as seven transmembrane receptors, from their identifying structure of seven $\alpha$-helices spanning the membrane. They can receive a variety of ligand classes from the extracellular environment, and stimulate intracellular signaling cascades that may begin with action of associated G-proteins [3]. Although GPCR in

\footnotetext{
* Correspondence: jloor@illinois.edu

Mammalian NutriPhysioGenomics, Department of Animal Sciences and

Division of Nutritional Sciences, University of Illinois, 1207 West Gregory

Drive, Urbana, IL 61801, USA
}

general are extensively-researched drug targets due to their abundance and activities, those which have metabolic roles may be targets for treating or preventing metabolic and inflammatory diseases in dairy cows, as well. This could especially be of value in the transition period, where prevalence rates and outcomes of diseases are often at their worst [4].

GPCR with fatty acids (FA), and especially longer-chain FA, ligands are among some of the most interesting targets, due to the ability of saturated versus unsaturated fats to evoke different signals within cells [5, 6], and for signaling potency to vary based on chain length and degree of saturation [7-9]. There is also potential to link nutrition, FA metabolism, and immunity among such signaling pathways [10]. For instance, GPR40 and GPR120 may be 
implicated in anti-inflammation in macrophages, but are currently of greater interest for their metabolic effects. These receptors have been connected with obesity, insulin responses, and inflammation subsequent to these conditions [10]. GPR40 may have a unique contribution to immune function, as it has been shown to stimulate calcium mobilization in bovine neutrophils, a necessary signal for neutrophil activation and function [11]. GPR84 has been identified in cells of both the innate and adaptive immune system, including PMNL, and plays a role in proinflammatory responses, e.g., cytokine production [10]. GPR109A also links metabolism and immunity; it has been detected in adipose and macrophages and primarily exerts anti-lipolytic effects [12]. For a summary of these genes and their functions, see Table $1[10,11]$.

The present study also involved an examination of GPCR in adipose tissue, and more specifically cows with different degrees of adiposity as evaluated through the body condition score (BCS) at $21 \mathrm{~d}$ prior to parturition. BCS represents energy storage status [13], which is vitally important to the peripartal dairy cow, as early lactation proceeds at the expense of stored energy [14]. What is considered as an optimal score can vary, and may instead be expressed as a range, but is currently thought to be around 3.25 near calving [15]. Generally, however, relatively higher prepartum or calving BCS is correlated with greater BCS [16] and/or body weight [17] loss postcalving. Thus, although all cows experience negative energy balance (NEB) after calving [4], higher BCS cows are at higher risk for deeper NEB and excess lipid mobilization - adverse conditions for an optimal transition. Lower BCS may be considered relatively more optimal for health, although very thin cows have been found to produce less milk [18]. Thus, comparison of FA-sensing receptor expression in both an optimal/thin and a suboptimal/fat group of cows (here, divided as $\mathrm{LO}=\mathrm{BCS} \leq 3.25$, and $\mathrm{HI}=\mathrm{BCS} \geq 3.75$, respectively) could be of value.

The effect of supplementing rumen-protected methionine (MET) was also considered for liver and blood polymorphonuclear leukocytes (PMNL) analyses of GPCR. Previous work by our group demonstrated that MET can improve liver function, immune and antioxidant status, milk yield and protein levels, and may also have beneficial effects on dry matter intake (DMI) around calving [19-21]. Since the GPCR studied here are closely linked to lipid and glucose metabolism and inflammation, it seemed worthwhile to investigate whether gene expression in liver or PMNL is changed with supplementation, and how that relates to observed cow-level effects.

Because the FFAR are not yet well-studied in ruminants [22], the aim of the present study was to assess patterns and levels of receptor expression in periparturient dairy cows. Furthermore, because BCS and supplemental MET can affect production, immune status, and metabolism, we hypothesized that there would be some differential expression between groups.

\section{Methods}

\section{Animals and treatments}

Cows in the present study were a subset from the experiment of Zhou et al. [21]. Cows were blocked according to lactation and calving measures, and fed the same close-up (1.52 Mcal/kg DM; -21 d until calving) and lactation (1.71 $\mathrm{Mcal} / \mathrm{kg}$ DM; calving until $+30 \mathrm{~d})$ diets as a total mixed ration (TMR) once daily $(0630 \mathrm{~h})$. Cows were housed in an enclosed, ventilated barn during the dry period and fed using an individual gate system (American Calan Inc., Northwood, $\mathrm{NH}$ ), and moved to a tie-stall barn with

Table 1 Genes of interest and their functions

\begin{tabular}{lll}
\hline Gene Name & Gene Function & References \\
\hline GPR40 & M/LCFA receptor expressed in pancreatic a- and $\beta$-cells, enteroendocrine cells, immune cells, taste buds, and & {$[8,11,38,48,66]$} \\
& the central nervous system. Stimulation invokes intracellular calcium response and ERK signaling, or increases \\
& in CAMP. Mediates insulin release from $\beta$-cells, glucagon release from a-cells, and incretins in the gastrointestinal \\
& tract in response to free fatty acid (FFA) ligands, playing a central role in glucose homeostasis. Promotes activation \\
& and superoxide production in bovine neutrophils. May regulate secretion of brain-derived neurotrophic factor in \\
& neuroblastoma cells.
\end{tabular}

GPR120 M/LCFA receptor expressed in adipocytes and adipose tissue, macrophages, enteroendocrine cells, pancreatic a-cells, taste buds, and lungs. Stimulation invokes intracellular calcium response and ERK signaling. Stimulation with $\omega$-3 FA leads to $\beta$-arrestin2-mediated inhibition of TAK1 (i.e.: anti-inflammatory signaling). Promotes glucose uptake via GLUT4 and G-protein-related insulin stimulatory effects in adipocytes. Promotes incretin (e.g., GLP-1) release in gastrointestinal tract, and glucagon release in a-cells. Reduces inflammatory gene expression in macrophages and adipose, as well as macrophage invasion into adipose tissue.

GPR84 MCFA receptor expressed in adipocytes and immune cells, including leukocytes. Expression is upregulated in macrophages by LPS. Promotes pro-inflammatory cytokine and chemokine signals. 
individual feed bunks after calving. Throughout these periods, diets were top-dressed with either no supplement $(\mathrm{CON})$, or Smartamine M (Adisseo NA) rumen-protected methionine (MET). Complete details of supplementation may be found elsewhere [21]. Lactating cows were milked three times daily (0600, 1400, and $2200 \mathrm{~h}$ ).

Ten and eleven cows from each group (CON and MET) were used in the present study to compare PMNL and liver gene expression, respectively. Additionally, twenty cows that had received adipose biopsies were retroactively grouped by their BCS (see below) at -3 wk from calving (i.e.: upon entry into the close-up dry period), such that 10 cows with $\mathrm{BCS} \geq 3.75$ ( $\mathrm{HI}$; avg. $=3.83 \pm 0.12$ ) were compared to 10 cows with $\mathrm{BCS} \leq 3.25(\mathrm{LO}$; avg. $=3.11 \pm 0.16$ ) for adipose gene expression. The effect of supplementation was not considered in this tissue.

\section{Sample collection}

The BCS were assigned weekly during the experiment, along with body weight measurements. BCS was determined on a scale of $1-5$ with quarter-point increments, where $1=$ thin and $5=$ obese. Two scores were given independently each week, so that the average was taken and used for statistical analyses and retroactive grouping. Individual and average BCS loss of cows in each group were also calculated between Prepartum (-21 d) and Postpartum $(+21 \mathrm{~d})$ time points. At $-10,+7$, and $+20 \mathrm{~d}$ from calving, energy balance (Table 2) was calculated as described previously [23] in the subset of cows which received adipose biopsies.

Blood was only collected from those cows receiving liver biopsies or scheduled for PMNL retrieval. Serum and plasma were collected for analyses into vacutainers (BD Vacutainer; BD and Co., Franklin Lakes, NJ) containing clot activator or lithium heparin, respectively, at $-10,+8$, and $+30 \mathrm{~d}$ relative to parturition. Blood for serum samples was kept at $21^{\circ} \mathrm{C}$, and blood for plasma kept on ice, until

Table 2 Least squares means of energy balance (EB) and energy balance as a percentage of requirements (EB \% Req) in transition cows with high (HI; BCS $\geq 3.75$ ) or low ( $\mathrm{LO}$; BCS $\leq 3.25$ ) body condition score prepartum and postpartum. This data only represents the subset of cows used for adipose gene expression

\begin{tabular}{|c|c|c|c|c|c|c|}
\hline & \multicolumn{2}{|l|}{$\mathrm{BCS}^{1}$} & \multirow[t]{2}{*}{$\mathrm{SEM}^{2}$} & \multicolumn{3}{|c|}{$P$-value } \\
\hline & $\overline{\mathrm{HI}}$ & LO & & $\overline{B C S}$ & Time & BCS $\times$ Time \\
\hline \multicolumn{7}{|l|}{ Prepartum } \\
\hline $\mathrm{EB}$ & 1.89 & 2.16 & 1.08 & 0.86 & - & - \\
\hline EB \% Req & 112.35 & 115.62 & 7.13 & 0.75 & - & - \\
\hline \multicolumn{7}{|l|}{ Postpartum } \\
\hline EB & $-11.87^{\mathrm{a}}$ & $-5.52^{b}$ & 2.00 & 0.03 & 0.03 & 0.14 \\
\hline EB \% Req & $70.85^{a}$ & $86.20^{\mathrm{b}}$ & 4.74 & 0.03 & $<0.01$ & 0.30 \\
\hline
\end{tabular}

${ }^{\mathrm{a}, \mathrm{b}}$ Statistical difference $(P<0.05)$ among time points within the same group ${ }^{1}$ Body condition score

${ }^{2}$ Largest standard error of the mean centrifugation. Methods for analyses of IL-1 $\beta$, reactive oxygen metabolites (ROM), and myeloperoxidase (MPO) as indicators of systemic inflammation and oxidative stress was reported previously [20].

Full protocols for relevant tissue biopsies have been previously described [24, 25]. Briefly, cows were given local anesthesia prior to biopsy. The same cows were not used for liver biopsies as for adipose biopsies. Liver was sampled via puncture biopsy at $-10,+7$, and $+30 \mathrm{~d}$ from parturition via puncture biopsy, while adipose biopsies from alternate sides of the tail-head region were taken at $-10,+7$, and $+20 \mathrm{~d}$ using a blunt dissection method. Both liver and adipose samples were snap-frozen in liquid nitrogen and transferred to a freezer at $-80{ }^{\circ} \mathrm{C}$ until RNA extraction and further analyses.

\section{PMN Isolation}

Blood samples for collection of PMNL were drawn into vacutainers containing acid citrate dextrose (ACD Solution A; Fisher Scientific) from the coccygeal vein at $-10,+7$, and $+30 \mathrm{~d}$ relative to parturition. Samples were placed on ice until PMNL isolation by sample centrifugation, cell lysing, and several rounds of centrifugation with PBS washing. Both purity and viability of PMNL were greater than $90 \%$. Complete details of this process can be found in Zhou et al. [26]. Briefly, a $50 \mu \mathrm{L}$ aliquot of PMNL was incubated for $15 \mathrm{~min}$ on ice with $100 \mu \mathrm{L}$ of primary anti-bovine granulocyte monoclonal antibody (Cat. No. BOV2067, Washington State University, Pullman, USA) solution $(15 \mu \mathrm{g} / \mathrm{mL}$ in $1 \times \mathrm{PBS})$. The aliquot was then washed twice with $2 \mathrm{~mL} 1 \times$ PBS and incubated for another $15 \mathrm{~min}$ on ice, protected from light, with $50 \mu \mathrm{L}$ of secondary phycoerythrin-labeled secondary antibody (Cat. No. 1020-09S, Southern Biotech, Birmingham, AL) $(4 \mu \mathrm{g} / \mathrm{mL}$ in $1 \times \mathrm{PBS})$, and $50 \mu \mathrm{L}$ of Propidium iodide $(50 \mu \mathrm{g} / \mathrm{mL})$ prior to flow cytometry. Isolated PMNL were homogenized at full speed in a solution of $2 \mathrm{~mL}$ TRIzol reagent (Invitrogen, Carlsbad, CA) with $1 \mu \mathrm{L}$ linear acrylamide (Ambion, Inc., Austin, TX). Homogenate was stored at $-80{ }^{\circ} \mathrm{C}$ in RNA-free microcentrifuge tubes (Fisher Scientific, Pittsburgh, PA).

\section{RNA Isolation}

To proceed with RNA extraction, $40 \mathrm{mg}$ liver and $200 \mathrm{mg}$ adipose were thawed and homogenized in QIAzol reagent (Qiagen, Hilden, Germany). Extraction of RNA was performed with the miRNeasy kit (Qiagen) following the manufacturer's protocols. Samples were treated on-column with DNaseI (Qiagen). Prior to storage, RNA purity was confirmed using a NanoDrop ND-1000 (NanoDrop Technologies, Rockland, $\mathrm{DE}) \mathrm{OD}_{260 \mathrm{~nm}} / \mathrm{OD}_{280 \mathrm{~nm}}$ ratio, and RNA quality was recorded using a 2100 Bioanalyzer (Agilent Technologies, Inc., Santa Clara, CA) RNA integrity number (RIN). All liver samples had RIN scores 
above 8.0. Average RIN scores for the other two tissues were as follows: $6.44 \pm 0.21$ for adipose and 6.68 \pm 0.02 for PMNL.

\section{Real-time Quantitative PCR}

Previous publications by our group [27] outlined the full protocols. Briefly, $100 \mathrm{ng}$ of RNA, plus reagents including: $1 \mu \mathrm{g}$ of dT18 (Operon Biotechnologies, Huntsville, AL), $1 \mu \mathrm{L}$ of $10 \mathrm{mmol} / \mathrm{L}$ dNTP mix (Invitrogen Corp., Carlsbad, CA), $1 \mu \mathrm{L}$ of random primers ( $3 \mathrm{mg} / \mu \mathrm{L}$; Invitrogen Corp.), and $10 \mu \mathrm{L}$ of DNase-/RNase-free water, were incubated at $65{ }^{\circ} \mathrm{C}$ for $5 \mathrm{~min}$, then placed on ice for $3 \mathrm{~min}$. Six $\mu \mathrm{L}$ of master mix, including: $5.5 \mu \mathrm{L}$ of $5 \times$ reaction buffer, $0.25 \mu \mathrm{L}$ (50 U) of RevertAid reverse transcriptase (Fermentas Inc., Glen Burnie, MD), and $0.25 \mu \mathrm{L}$ of RNase inhibitor (10 U, Promega, Madison, WI), was then added to complete cDNA synthesis.

Primer design protocols have also been published previously [28]. Except for bovine GPR4O [29], primer sequences were obtained using Primer Express 3.0. Primer information and obtained products are listed in Additional file 1: Table S1 and S2, respectively. Quantitative PCR was performed using $4 \mu \mathrm{L}$ of diluted cDNA plus a mixture of $5 \mu \mathrm{L}$ of $1 \times$ SYBR Green master mix (Applied Biosystems, CA), $0.4 \mu \mathrm{L}$ each of the $10 \mu \mathrm{mol} / \mathrm{L}$ forward and reverse primers, and $0.2 \mu \mathrm{L}$ of DNase- $/$ RNase-free water in a MicroAmp Optical 384-Well Reaction Plate (Applied Biosystems, Foster City, CA). Each sample was run in duplicate, while a negative control and serially diluted, pooled cDNA were run in triplicate to create a 6-point relative standard curve (User Bulletin \#2, Applied Biosystems). PCR reactions were performed in an ABI Prism 7900 HT SDS instrument (Applied Biosystems) under the following conditions: 2 min at $50{ }^{\circ} \mathrm{C}, 10 \mathrm{~min}$ at $95{ }^{\circ} \mathrm{C}, 40$ cycles of $15 \mathrm{~s}$ at $95{ }^{\circ} \mathrm{C}$ (denaturation), and $1 \mathrm{~min}$ at $60{ }^{\circ} \mathrm{C}$ (annealing plus extension). Gene expression was normalized using the geometrical mean of three appropriate internal control genes: GAPDH and RPS9 for all tissues, along with $A C T B$ for adipose and $U X T$ for liver and PMNL [25, 27, 30]. Genes were considered not expressed when the standard curve had slope $-3.50>\mathrm{y}>-3.00$ and $\mathrm{Ct}>30$. At least for the $\mathrm{Ct}$ threshold, the criterion is consistent with our established protocols aimed in part at reducing the unreliability of data that often occurs at $>30 \mathrm{Ct}[25,27,28,30]$. In that context, it is important to highlight that in recent studies dealing with the study of FFAR the mean $\mathrm{Ct}$ for quantification of GPR40 (which was undetectable using our thresholds) ranged from 31.4 for adipose and liver [31] to 35.7 for adipose [32]. Although it could be possible that the size of the amplicon for the GPR40 primer [29] was too long and led to poor amplification efficiency, Yonezawa et al. [29] verified the identity of bovine GPR40 by sequencing (as did we; see Additional Table S2) and used it successfully with bovine mammary tissue. Unfortunately, there was no information on amplicon size for the GPR40 primer used in the work of Friedrichs et al. [31, 32]. The qPCR performance is reported for adipose, liver, and PMNL in Additional file 1: Table S3.

\section{Statistical analysis}

Prior to analysis, expression data were $\log _{2}$ normalized. All data sets (i.e.: blood parameters, energy balance, and qPCR) were then subject to ANOVA using repeated measures ANOVA with PROC MIXED in SAS (v 9.2; SAS Institute Inc., Cary, NC). The statistical model for adipose included time $(-10,+7,+20 \mathrm{~d})$, BCS (HI, LO), and their interaction as fixed effects. Energy balance was analyzed pre- and postpartum. The model for liver and PMNL gene expression, and blood parameters, included time $(-10,+7$, +30 d), methionine supplementation (MET, CON), and their interaction as fixed effects. The random effect was cow, nested within treatment. The Kenward-Roger statement was used for computing the denominator degrees of freedom, with sp(pow) as the covariance structure. Energy balance used Compound Symmetry as the covariance structure postpartum. Previous $305 \mathrm{~d}$ lactation and parity were used as covariates for blood analysis, and parity was used as a covariate for energy balance. When not significant, covariates were removed from the model. Data were considered significant at $P \leq 0.05$ using the PDIFF statement in SAS. Expression data in Tables 3 and 5 are reported as the $\log _{2}$ back-transformed least squares means.

\section{Results \\ Body condition score experiment Energy balance}

Although there was no difference in energy balance by BCS prepartum $(P=0.86)$ (Table 2), cows in the HI BCS group were in more NEB $(P=0.03)$ during the postpartum period.

\section{Adipose}

GPR40 was not expressed in adipose tissue. GPR84 expression was significantly lower $(P<0.05)$ prepartum than postpartum (Table 3 ). There was also an interaction effect $(P=0.03)$ of $\mathrm{BCS} \times$ time, such that expression was higher in LO than in $\mathrm{HI}$ cows at $+7 \mathrm{~d}$. There was also a significant time effect $(P<0.01)$ on expression of GPR120, where expression was highest prepartum, and decreased at both of the postcalving time points. Expression of both GPR120 and GPR109A tended $(P=0.08$ and 0.06$)$ to be greater in LO than in HI. There was also a tendency $(P=0.08)$ due to the time effect on GPR109A, mainly for the difference between +7 and $+20 \mathrm{~d}$. 
Table 3 Log $_{2}$-backtransformed least squares means of adipose gene expression data in transition cows with high (Hl; BCS $\left.\geq 3.75\right)$ or low (LO; BCS $\leq 3.25)$ body condition score at $-10,+7$, and +20 d from calving

\begin{tabular}{|c|c|c|c|c|c|c|c|c|c|c|c|c|c|c|c|}
\hline \multirow{3}{*}{ Gene } & \multirow{2}{*}{\multicolumn{2}{|c|}{$\mathrm{BCS}^{1}$}} & \multirow{2}{*}{\multicolumn{3}{|c|}{ Time }} & \multicolumn{6}{|c|}{ BCS $\times$ Time } & \multirow{3}{*}{$\mathrm{SEM}^{2}$} & \multirow{2}{*}{\multicolumn{3}{|c|}{$P$-value }} \\
\hline & & & & & & \multicolumn{3}{|l|}{$\overline{\mathrm{HI}}$} & \multicolumn{3}{|l|}{ LO } & & & & \\
\hline & $\overline{\mathrm{HI}}$ & $\mathrm{LO}$ & -10 & +7 & +20 & -10 & +7 & +20 & -10 & +7 & +20 & & $\overline{B C S}$ & Time & BCS $\times$ Time \\
\hline GPR40 & Not $\epsilon$ & pressec & & & & & & & & & & & & & \\
\hline GPR84 & 0.37 & 0.41 & $0.19^{\mathrm{a}}$ & $0.69^{b}$ & $0.46^{\mathrm{b}}$ & $0.21^{\mathrm{a}}$ & $0.39^{\mathrm{a}, \mathrm{b} *}$ & $0.61^{b}$ & $0.17^{\mathrm{a}}$ & $1.21^{b *}$ & $0.34^{\mathrm{a}}$ & 0.40 & 0.62 & $<0.01$ & 0.03 \\
\hline GPR120 & 0.46 & 0.72 & $1.69^{\mathrm{a}}$ & $0.49^{\mathrm{b}}$ & $0.22^{c}$ & 1.36 & 0.37 & 0.19 & 2.09 & 0.67 & 0.26 & 0.64 & 0.08 & $<0.01$ & 0.89 \\
\hline GPR109A & 1.05 & 1.30 & 1.12 & 1.40 & 1.02 & 1.13 & 1.16 & 0.89 & 1.10 & 1.68 & 1.17 & 0.22 & 0.06 & 0.08 & 0.33 \\
\hline
\end{tabular}

a,b,c Statistical difference $(P<0.05)$ among time points within the same group

* Statistical difference $(P<0.05)$ between groups within time points

${ }^{1}$ Body condition score

${ }^{2}$ Largest standard error of the mean

\section{Rumen-protected methionine experiment} Inflammation and oxidative stress biomarkers

Overall, cows in MET had lower $(P<0.05)$ concentrations of IL-1 $\beta$ and ROM but had greater $(P<0.05)$ concentration of MPO (Table 4).

\section{Liver}

Neither GPR40 nor GPR120 were expressed in liver (Table 5). For GPR84 and GPR109A, there were no significant differences $(P>0.15)$ or tendencies for effects of MET, time, or the interaction.

\section{PMNL}

GPR120 was not expressed in PMNL (Table 5). Among the other three genes, there were significant differences $(P<0.05)$ between MET and CON for GPR40 and GPR84, such that GPR40 was lower in MET, and GPR84 was higher in MET. GPR40 expression also differed across time $(P=0.04)$, such that cows had significantly greater expression at $-10 \mathrm{~d}$ than at $+30 \mathrm{~d}$, decreasing (albeit not significantly) in between. GPR109A tended $(P=0.09)$ to be higher in MET PMNL than in CON.

Table 4 Least squares means of immune biomarker concentrations in blood in transition cows supplemented with rumen-protected methionine (MET) or unsupplemented (CON) at $-10,+7$, and +30 d. This data only represents the subset of cows used for polymorphonuclear leukocyte (PMNL) gene expression

\begin{tabular}{|c|c|c|c|c|c|c|}
\hline \multirow[t]{2}{*}{ Parameter } & \multicolumn{2}{|l|}{ Diet } & \multirow[t]{2}{*}{$\mathrm{SEM}^{1}$} & \multicolumn{3}{|c|}{$P$-value } \\
\hline & MET & $\mathrm{CON}$ & & Diet & Time & Diet $\times$ Time \\
\hline$I L-1 \beta^{2}$ & $3.63^{\mathrm{a}}$ & $5.74^{b}$ & 0.69 & 0.05 & 0.17 & 0.70 \\
\hline $\mathrm{ROM}$ & $12.29^{a}$ & $14.20^{\mathrm{b}}$ & 0.23 & $<0.01$ & $<0.01$ & 0.05 \\
\hline MPO & $466.87^{a}$ & $405.18^{b}$ & 15.89 & 0.02 & 0.14 & 0.44 \\
\hline
\end{tabular}

${ }^{a, b}$ Statistical difference $(P \leq 0.05)$ among time points within the same group ${ }^{1}$ Largest standard error of the mean

${ }^{2}$ Significance $(P<0.05)$ for parity in the model

\section{Discussion}

Body condition score

\section{Adipose tissue}

Postpartum, transition cows can experience stress-induced, pathogen-independent inflammation, as marked by pro-inflammatory cytokines and acute-phase proteins (APP) in the blood [33]. Furthermore, expression of chemoattractants and cytokines within adipose tissue indicates some degree of local inflammation, which has been postulated as a homeorhetic mechanism to aid lactation $[34,35]$. This theory is supported by the knowledge that cytokines present during inflammation encourage lipolysis [34], the "metabolic hallmark" of transition [36]. Here, both the function and the temporal expression of GPR84 match physiologic adaptations in the cow, indicating that effects of inflammation in adipose are partly mediated through this receptor.

An interaction of BCS $\times$ time at $+7 \mathrm{~d}$, where $\mathrm{LO}$ cows had much greater expression of GPR84 than $\mathrm{HI}$ cows also provides evidence of the pro-inflammatory role for GPR84 in cattle. Biomarkers like haptoglobin, bilirubin, and paraoxonase have been used to indicate peripartal inflammation through the first 2-3 wk of lactation [37]. Here, although blood biomarker data were unavailable, the surge in GPR84 expression may also indicate greater inflammation in LO cows, at least within the adipose tissue depot [38]. This may not necessarily be mirrored at a systemic level since cows with higher BCS are normally associated with greater overall inflammation and lower health status [13]. Despite this, thin cows can still be health-compromised during the transition period $[13,39]$. Barring clinical or subclinical disease, inflammatory signals resolve toward the end of the transition period [37], which parallels the return of GPR84 expression to prepartum levels.

If the above holds true, GPR84-mediated inflammation could also help explain production in these cows. Inflammation in early lactation has been connected with poorer performance (i.e. milk yield; [33]), and in fact, 
Table 5 Log 2 -backtransformed least squares means of liver and polymorphonuclear leukocyte (PMNL) gene expression data in transition cows supplemented with rumen-protected methionine (MET) or unsupplemented (CON) at $-10,+7$, and $+30 \mathrm{~d}$ from calving

\begin{tabular}{|c|c|c|c|c|c|c|c|c|c|c|c|c|c|c|c|}
\hline \multirow{3}{*}{ Gene } & \multirow{2}{*}{\multicolumn{2}{|c|}{ Diet }} & \multirow{2}{*}{\multicolumn{3}{|c|}{ Time }} & \multicolumn{6}{|c|}{ Diet $\times$ Time } & \multirow{3}{*}{ SEM $^{1}$} & \multirow{2}{*}{\multicolumn{3}{|c|}{$P$-value }} \\
\hline & & & & & & \multicolumn{3}{|l|}{$\overline{\mathrm{MET}}$} & \multicolumn{3}{|l|}{ CON } & & & & \\
\hline & $\overline{\mathrm{MET}}$ & $\overline{C O N}$ & -10 & +7 & +30 & -10 & +7 & +30 & -10 & +7 & +30 & & $\overline{\text { Diet }}$ & Time & Diet $\times$ Time \\
\hline \multicolumn{16}{|l|}{ Liver } \\
\hline GPR40 & \multicolumn{15}{|c|}{ Not expressed } \\
\hline GPR84 & 0.77 & 0.84 & 0.88 & 0.74 & 0.80 & 0.85 & 0.73 & 0.75 & 0.91 & 0.75 & 0.86 & 0.14 & 0.64 & 0.25 & 0.89 \\
\hline GPR120 & \multicolumn{15}{|c|}{ Not expressed } \\
\hline GPR109A & 0.51 & 0.53 & 0.64 & 0.48 & 0.46 & 0.57 & 0.52 & 0.44 & 0.72 & 0.44 & 0.47 & 0.15 & 0.77 & 0.22 & 0.61 \\
\hline \multicolumn{16}{|l|}{ PMNL } \\
\hline GPR40 & $0.85^{*}$ & $1.13^{*}$ & $1.15^{\mathrm{a}}$ & $0.95^{a, b}$ & $0.85^{\mathrm{b}}$ & 1.00 & 0.80 & 0.77 & 1.33 & 1.14 & 0.94 & 0.17 & 0.04 & 0.04 & 0.78 \\
\hline GPR84 & $1.49^{*}$ & $0.65^{*}$ & 0.96 & 1.05 & 0.96 & 1.22 & 1.82 & 1.49 & 0.75 & 0.60 & 0.61 & 0.64 & 0.04 & 0.93 & 0.51 \\
\hline GPR120 & \multicolumn{15}{|c|}{ Not expressed } \\
\hline GPR109A & 1.34 & 0.87 & 1.26 & 0.91 & 1.10 & 1.42 & 1.31 & 1.28 & 1.11 & 0.63 & 0.94 & 0.44 & 0.09 & 0.60 & 0.71 \\
\hline
\end{tabular}

${ }^{\mathrm{a}, \mathrm{b}}$ Statistical difference $(P<0.05)$ among time points within the same group

* Statistical difference $(P<0.05)$ between groups within time points

${ }^{1}$ Largest standard error of the mean

through the first month, milk yield from LO cows was numerically, albeit not statistically, lower than HI cows (39 kg/d vs. $42 \mathrm{~kg} / \mathrm{d}$; data not shown). In a recent study [17], Pires et al. obtained similar results: numerically, low BCS cows had lower production than medium or high BCS cows. Further work including more cows, as well as immune biomarkers concurrent with gene expression, will be necessary to elucidate the potential involvement of GPR84 and validity of such relationships.

Contrary to GPR84, GPR120 is primarily an antiinflammatory receptor [8]. Thus, lower expression over time potentially reinforces evidence of postpartal inflammation, although without a lessening effect by 3 week postpartum. Its metabolic role may explain this pattern: GPR120 stimulates adipogenesis and differentiation, rather than lipolysis [40]. As necessity for lipolysis increases through early lactation NEB [14], expression of GPR120 should decrease, as observed here. Receptor activation in adipose also improves insulin sensitivity [41]. Because insulin resistance in peripheral tissues is important for pushing available glucose to the mammary gland post-calving [42], lower expression of GPR120 in adipose should be expected, and may be a necessary part of the transcriptome adaptation to milk synthesis.

To a lesser extent, limited expression could also be a regulatory mechanism. As lipolysis occurs, releasing primarily long-chain FA (LCFA) (i.e. GPR120 ligands) to the blood [43], signaling may provide negative feedback to prevent hyperactivation. In some cases, GPR120 can activate $\beta$-arrestin 2 , which promotes receptor internalization and prevents continuous ligand-sensing [44]; perhaps gene expression is used as an additional level of control, or acts as a primary regulatory mechanism when alternate pathways are activated.
Both of the above ideas may explain why HI cows tended to have lower overall GPR120 expression. As previously mentioned, milk yield of HI cows was $\sim 3 \mathrm{~kg} / \mathrm{d}$ greater, numerically. Greater milk production translates to greater glucose requirements [36], and gene expression should reflect a heightened need for peripheral insulin resistance. To produce milk during NEB, HI cows may also mobilize more of their body fat reserves which we also detected in this study, leading to higher FA mobilization and circulating FA $[16,39]$. The marked NEB postpartum in HI cows supports this idea. As GPR120 interacts with free LCFA, a negative response on gene expression may prevent further signaling at a time when that could be counterproductive. Certainly, going forward, this receptor could be an interesting metabolic target in the transition period.

The finding that GPR109A tends to have greater expression in LO than in HI cows is not surprising. Studies of GPR109A indicated that it is a primary anti-lipolytic receptor in adipose tissue [45]. The lower BCS in LO cows was indicative of potentially lower amount of stored fat, and greater expression of this receptor could be a mechanism to maintain as much of their already-reduced body condition as possible. Smaller BCS losses between the beginning of the close-up period $(-21 \mathrm{~d})$ and both postpartum time points $(+21 \mathrm{~d})$ in LO cows compared with $\mathrm{HI}$ cows may provide evidence in support of this hypothesis (BCS loss of 0.80 versus 0.40 ). To address the species-specific effects of GPR109A on lipolysis, that is, whether in ruminants it has temporary and/or rebound effects as in humans, or longer-term FA-lowering effects as in rodents [46], plasma FA from multiple time points should be considered. Although no blood data were available for the subset of cows with adipose biopsies, amount 
of circulating FA can be correlated with energy balance (EB) [36]. Thus, with better EB (i.e.: more shallow NEB) than $\mathrm{HI}$ cows at both time points postpartum, it can be assumed that LO cows had lower circulating FA, meaning that GPR109A may be effective over some period of time in cattle. Blood analyses will be useful to confirm this idea.

For this reason, a tendency for greater GPR109A expression $+7 \mathrm{~d}$ after calving, regardless of BCS, was unexpected. The nadir in energy balance, when low DMI coincides with high lactation requirements, typically occurs within three weeks following calving. As previously mentioned, this tends to correspond with lipomobilization; in fact, peak levels of basal and norepinephrinestimulated lipolysis occur around $+10 \mathrm{~d}$ [14]. Thus, it appears that high rates of lipolysis can occur in spite of the anti-lipolytic influence of GPR109A.

This could be due to a greater net signal for fat mobilization over storage brought on by calving and initiation of lactation. Because GPR109A signaling involves a decrease in cAMP levels that inhibits hormone-sensitive lipase and prevents release of FA [45], it is possible that parturition- and lactation-induced flux in hormone levels themselves (e.g., increased catecholamines and decreased insulin) are more influential on hormone-sensitive lipase than GPCR signaling [47]. More information could become available with trials on GPR109A in periparturient animals.

\section{Rumen-protected methionine supplementation Liver}

It is not altogether surprising that the genes of interest were not expressed, or were expressed at low levels in the liver. Although these GCPR can be widely expressed throughout the body [8], few studies identified the liver as a major site of expression for these particular genes. In fact, GPR40 [46, 47] and GPR109A [43, 48] have been reported as not detected in liver, and GPR120 has been reported as not detected, except in Kupffer cells (i.e.: macrophages), in the liver $[49,50]$. In the present study, the fact that GPR40 and GPR120 were not detected agrees with the literature.

The barely detectable expression of GPR109A and GPR84, and the lack of differences between groups or across time, indicates that these genes may typically be expressed at very low levels, if at all, in bovine liver. Greater numbers of cows, and/or protein detection methods, should be used in future studies to confirm the presence or absence of these receptors within the liver.

Nonetheless, the genes of interest do play an important role in function and diseases in the liver. It is therefore plausible that effects of these GPCR on the liver are mostly indirect, as a result of signaling that originates in other peripheral tissues or immune cells. Notably, the acute, insulin-promoting effects of GPR120 [41], and
GPR109A signaling to reduce hormone-sensitive lipase [45] in adipose tissue, could protect against excess lipid mobilization preceding fatty liver. Conversely, activation of GPR40 in pancreatic $\beta$-cells could signal hyperinsulinemia and increased risk of lipid accumulation in the liver [51]. Therefore, for the present genes of interest, systemic metabolic networks - rather than localized pathways may provide better insight as to hepatic responses in bovines. Alternatively, other families of receptors, e.g., peroxisome proliferator-activated receptor (PPAR), could contribute more to direct outcomes of relevant ligands (i.e.: LCFA) in the liver [52].

\section{PMNL}

Neutrophils are the only tissue in which GPR4O was detected. Since GPR40 has already been implicated in calcium-dependent degranulation and superoxide production in bovine neutrophils [53], its presence was certainly expected. Its downregulation over time suggests lower PMNL activity postpartum. Indeed, it is well-known that hormones and NEB contribute to immunosuppression post-calving [54-56]. However, it is curious that MET cows had lower expression than CON despite having greater phagocytosis and oxidative burst capacity when challenged in vitro with a bacterial pathogen [20] and higher plasma levels of myeloperoxidase (Table 4) [20]. Instead, it seems that MET could indirectly affect GPR4O expression through substrate (i.e. fatty acid) availability, because inflammation can promote lipolysis [57], but MET supplementation appears to benefit the inflammatory status (i.e. lower IL-1 $\beta$ and ROM) [34]. However, MET supplementation did not affect circulating FA levels [21]. Thus, the role of MET supplementation in regulating GPR40 expression needs further investigation.

In contrast, GPR84 upregulation in MET agrees with previous data describing enhanced immune response (i.e.: phagocytosis and respiratory burst) in these cows [20]. GPR84 expression can be stimulated by lipopolysaccharide (LPS), and subsequent signaling produces pro-inflammatory signals, demonstrating that receptor function is tied to immune responses [10]. In agreement, in vivo data revealed that supplementation with MCFA (i.e.: GPR84 ligands) in the transition period lessened neutrophil apoptosis [58], thereby improving antimicrobial capacity of the cells [59]. S Piepers and S De Vliegher [58] hypothesized that GPCR signaling could be at least partly responsible for the improvement in cell viability, and the present study provides evidence that GPR84 could specifically play a role.

Interestingly, GPR109A also tended to be upregulated in MET PMNL vs. CON. Like GPR84, GPR109A expression can be induced by LPS [12], yet with opposite outcome: GPR109A activates apoptosis in neutrophils [60]. As noted above, apoptosis should correspond with lower PMNL function, but this did not occur. On the other hand, 
because apoptosis promotes resolution of inflammation [61], GPR109A expression concurs with the largely antiinflammatory environmental conditions. Possibly, with the influence of MET to lower inflammation (as demonstrated by Zhou et al. [21]), neutrophils maintain their function over a short lifespan [62]. To aid in rapid clearance of aged neutrophils and maintenance of a stable environment, MET cells would induce apoptosis versus necrosis [61]. In this way, GPR109A may help protect transition cows from chronic inflammation. More in-depth studies would be needed, but if true, this could provide a new context in which to study niacin as a transition feed supplement [63-65].

\section{Conclusions}

Conditions which are present in ruminants and cause metabolic disorders and clinical disease near calving: negative energy balance, lipid mobilization, insulin resistance, and immunosuppression, closely resemble dysregulated metabolic systems in human diseases. Thus, molecular targets in human medicine may translate as targets for the transition cow. The present GPCR show promise for such work. Although none were expressed well in the liver, their contributions to inflammation, insulin resistance, and lipolysis in adipose indicate that they may indirectly affect liver accumulation of fat. The GPCR-modulated environment may also contribute to level of milk production and severity of systemic inflammation in early lactation. Additionally, the differences between BCS groups highlight the role of the transcriptome in coordinating lipid metabolism and energy status, and differences between MET and CON reinforce previous findings and demonstrate potential networks for immune-enhancing action of supplemental methionine. Thus, the present GPCR and related receptors (e.g., FFAR2 and FFAR3) are suggested as continued areas of research in bovine to improve transition health.

\section{Additional file}

Additional file 1: Table S1. Forward and reverse primer information for genes of interest. Table S2. PCR product sequences obtained using primers listed in Table 2. Table S3. qPCR performance of GPR40, GPR120, GPR84, and HCAR2/3 in adipose, liver, and polymorphonuclear leukocytes (PMNL). (DOCX $16 \mathrm{~kb})$

\footnotetext{
Abbreviations

APP: Acute phase protein; BCS: Body condition score; CON: Control-fed; DMI: Dry matter intake; EB: Energy balance; FA: Fatty acid; FFAR: Free fatty acid receptor; GPCR/GPR: G-protein coupled receptor;

HCAR: Hydroxycarboxylic acid receptor; HI: High BCS; IL-1B: Interleukin 13; LCFA: Long-chain fatty acids; LO: Low BCS; LPS: Lipopolysaccharide; MCFA: Medium-chain fatty acids; MET: Methionine-supplemented; NEB: Negative energy balance; PMNL: Polymorphonuclear leukocytes; PPAR: Peroxisome proliferator-activated receptor; qPCR: quantitative polymerase chain reaction; RIN: RNA integrity number; ROM: Reactive oxygen species; TMR: Total mixed ration.
}

\section{Acknowledgements}

Alea Agrawal is a recipient of a Jonathan Baldwin Turner MS fellowship from the University of Illinois (Urbana-Champaign). Z. Zhou is recipient of a fellowship from China Scholarship Council (CSC) to perform his PhD studies at the University of Illinois (Urbana-Champaign). The funders had no role in the design of the study and collection, analysis, and interpretation of data and in writing of the manuscript.

\section{Funding}

Not applicable.

\section{Availability of data and materials}

The datasets during and/or analyzed during the current study are available from the corresponding author on reasonable request.

\section{Authors' contributions}

A Agrawal, A Alharthi, MVR, and ZZ performed analyses and analyzed data. $J\lrcorner L$ conceived the animal experiments. A Agrawal wrote the manuscript. All authors approved the final version of the manuscript.

\section{Authors' information}

A. Agrawal, MS, University of Illinois, Urbana, Illinois, 61801, USA. A. Alharthi, MS, University of Illinois, Urbana, Illinois, 61801, USA. M. Vailati-Riboni is PhD candidate at the University of Illinois (Urbana-Champaign). Z. Zhou is PhD degree candidate at University of Illinois, Urbana, Illinois, 61801, USA. J. J. Loor is Associate Professor in the Department of Animal Sciences, University of Illinois, Urbana, Illinois, 61801, USA.

\section{Competing interests}

The authors declare that they have no competing interests.

\section{Consent for publication}

Not applicable.

\section{Ethics approval and consent to participate}

All procedures for this study (protocol no. 13023) were approved by the Institutional Animal Care and Use Committee of the University of Illinois.

Received: 9 August 2016 Accepted: 9 February 2017

Published online: 01 March 2017

\section{References}

1. Perez DM. The evolutionarily triumphant G-protein-coupled receptor. Mol Pharmacol. 2003;63(6):1202-5.

2. Hanlon CD, Andrew DJ. Outside-in signaling-a brief review of GPCR signaling with a focus on the Drosophila GPCR family. J Cell Sci. 2015;128(19):3533-42.

3. Fredriksson $R$, Lagerstrom MC, Lundin LG, Schioth HB. The G-protein-coupled receptors in the human genome form five main families. Phylogenetic analysis, paralogon groups, and fingerprints. Mol Pharmacol. 2003;63(6):1256-72.

4. Drackley JK. ADSA Foundation Scholar Award. Biology of dairy cows during the transition period: the final frontier? J Dairy Sci. 1999;82(11):2259-73.

5. Kwon B, Lee HK, Querfurth HW. Oleate prevents palmitate-induced mitochondrial dysfunction, insulin resistance and inflammatory signaling in neuronal cells. Biochim Biophys Acta. 2014;1843(7):1402-13.

6. Lee JY, Plakidas A, Lee WH, Heikkinen A, Chanmugam P, Bray G, et al. Differential modulation of Toll-like receptors by fatty acids: preferential inhibition by n-3 polyunsaturated fatty acids. J Lipid Res. 2003;44(3):479-86.

7. Briscoe CP, Tadayyon M, Andrews JL, Benson WG, Chambers JK, Eilert MM, et al. The orphan G protein-coupled receptor GPR40 is activated by medium and long chain fatty acids. J Biol Chem. 2003;278(13):11303-11.

8. Miyamoto J, Hasegawa S, Kasubuchi M, Ichimura A, Nakajima A, Kimura I. Nutritional Signaling via Free Fatty Acid Receptors. Int J Mol Sci. 2016;17(4):450.

9. Stein DT, Stevenson BE, Chester MW, Basit M, Daniels MB, Turley SD, et al. The insulinotropic potency of fatty acids is influenced profoundly by their chain length and degree of saturation. J Clin Invest. 1997;100(2):398-403.

10. Alvarez-Curto E, Milligan G. Metabolism meets immunity: The role of free fatty acid receptors in the immune system. Biochem Pharmacol. 2016;114:3-13.

11. Hidalgo MA, Nahuelpan C, Manosalva C, Jara E, Carretta MD, Conejeros I, et al. Oleic acid induces intracellular calcium mobilization, MAPK 
phosphorylation, superoxide production and granule release in bovine neutrophils. Biochem Biophys Res Commun. 2011;409(2):280-6.

12. Feingold KR, Moser A, Shigenaga JK, Grunfeld C. Inflammation stimulates niacin receptor (GPR109A/HCA2) expression in adipose tissue and macrophages. J Lipid Res. 2014;55(12):2501-8.

13. Roche JR, Friggens NC, Kay JK, Fisher MW, Stafford KJ, Berry DP. Invited review: Body condition score and its association with dairy cow productivity, health, and welfare. J Dairy Sci. 2009;92(12):5769-801.

14. Bauman DE, Currie WB. Partitioning of nutrients during pregnancy and lactation: a review of mechanisms involving homeostasis and homeorhesis. J Dairy Sci. 1980;63(9):1514-29.

15. Bewley JM, Schutz MM. Review: An interdisciplinary review of body condition scoring for dairy cattle. Prof Anim Sci. 2008;24:507-29.

16. Roche JR, Macdonald KA, Burke CR, Lee JM, Berry DP. Associations among body condition score, body weight, and reproductive performance in seasonal-calving dairy cattle. J Dairy Sci. 2007;90(1):376-91.

17. Pires JA, Delavaud C, Faulconnier Y, Pomies D, Chilliard Y. Effects of body condition score at calving on indicators of fat and protein mobilization of periparturient Holstein-Friesian cows. J Dairy Sci. 2013;96(10):6423-39.

18. Rukkwamsuk T, Kruip TA, Wensing T. Relationship between overfeeding and overconditioning in the dry period and the problems of high producing dairy cows during the postparturient period. Vet Q. 1999;21(3):71-7.

19. Li C, Batistel F, Osorio JS, Drackley JK, Luchini D, Loor JJ. Peripartal rumenprotected methionine supplementation to higher energy diets elicits positive effects on blood neutrophil gene networks, performance and liver lipid content in dairy cows. J Anim Sci Biotechnol. 2016;7:18.

20. Zhou Z, Bulgari O, Vailati-Riboni M, Trevisi E, Ballou MA, Cardoso FC, et al. Rumen-protected methionine compared with rumen-protected choline improves immunometabolic status in dairy cows during the peripartal period. J Dairy Sci. 2016;99(11):8956-69.

21. Zhou Z, Vailati-Riboni M, Trevisi E, Drackley JK, Luchini DN, Loor JJ. Better postpartal performance in dairy cows supplemented with rumen-protected methionine than choline during the peripartal period. J Dairy Sci. 2016;99(11):8716-32.

22. Bionaz M, Osorio J, Loor JJ. TRIENNIAL LACTATION SYMPOSIUM: Nutrigenomic in dairy cows: Nutrients, transcription factors, and techniques. J Anim Sci. 2015;93(12):5531-53.

23. Osorio JS, Ji P, Drackley JK, Luchini D, Loor JJ. Supplemental Smartamine M or MetaSmart during the transition period benefits postpartal cow performance and blood neutrophil function. J Dairy Sci. 2013;96(10):6248-63.

24. Dann HM, Litherland NB, Underwood JP, Bionaz M, D'Angelo A, McFadden JW, et al. Diets during far-off and close-up dry periods affect periparturient metabolism and lactation in multiparous cows. J Dairy Sci. 2006;89(9):3563-77.

25. Ji P, Osorio JS, Drackley JK, Loor JJ. Overfeeding a moderate energy diet prepartum does not impair bovine subcutaneous adipose tissue insulin signal transduction and induces marked changes in peripartal gene network expression. J Dairy Sci. 2012;95(8):4333-51.

26. Zhou Z, Bu DP, Vailati Riboni M, Khan MJ, Graugnard DE, Luo J, et al. Prepartal dietary energy level affects peripartal bovine blood neutrophil metabolic, antioxidant, and inflammatory gene expression. J Dairy Sci. 2015;98(8):5492-505.

27. Moyes KM, Graugnard DE, Khan MJ, Mukesh M, Loor JJ. Postpartal immunometabolic gene network expression and function in blood neutrophils are altered in response to prepartal energy intake and postpartal intramammary inflammatory challenge. J Dairy Sci. 2014;97(4):2165-77.

28. Bionaz M, Loor JJ. Gene networks driving bovine milk fat synthesis during the lactation cycle. BMC Genomics. 2008:9:366.

29. Yonezawa T, Haga S, Kobayashi Y, Katoh K, Obara Y. Unsaturated fatty acids promote proliferation via ERK1/2 and Akt pathway in bovine mammary epithelial cells. Biochem Biophys Res Commun. 2008;367(4):729-35.

30. Jacometo CB, Zhou Z, Luchini D, Trevisi E, Correa MN, Loor JJ. Maternal rumen-protected methionine supplementation and its effect on blood and liver biomarkers of energy metabolism, inflammation, and oxidative stress in neonatal Holstein calves. J Dairy Sci. 2016;99(8):6753-63.

31. Friedrichs $P$, Saremi B, Winand S, Rehage J, Danicke S, Sauerwein H, et al. Energy and metabolic sensing $G$ protein-coupled receptors during lactationinduced changes in energy balance. Domest Anim Endocrinol. 2014;48:33-41.

32. Friedrichs $P$, Sauerwein $H$, Huber $K$, Locher $L$, Rehage J, Meyer U, et al. Expression of metabolic sensing receptors in adipose tissues of periparturient dairy cows with differing extent of negative energy balance. Animal. 2016;10(4):623-32.

33. Bertoni G, Trevisi E, Han X, Bionaz M. Effects of inflammatory conditions on liver activity in puerperium period and consequences for performance in dairy cows. J Dairy Sci. 2008;91(9):3300-10.
34. Farney JK, Mamedova LK, Coetzee JF, KuKanich B, Sordillo LM, Stoakes SK, et al. Anti-inflammatory salicylate treatment alters the metabolic adaptations to lactation in dairy cattle. Am J Physiol Regul Integr Comp Physiol. 2013;305(2):R110-7.

35. Vailati-Riboni M, Kanwal M, Bulgari O, Meier S, Priest NV, Burke CR, et al. Body condition score and plane of nutrition prepartum affect adipose tissue transcriptome regulators of metabolism and inflammation in grazing dairy cows during the transition period. J Dairy Sci. 2016;99(1):758-70.

36. Bell AW. Regulation of organic nutrient metabolism during transition from late pregnancy to early lactation. J Anim Sci. 1995;73(9):2804-19.

37. Bionaz M, Trevisi E, Calamari L, Librandi F, Ferrari A, Bertoni G. Plasma paraoxonase, health, inflammatory conditions, and liver function in transition dairy cows. J Dairy Sci. 2007:90(4):1740-50.

38. Hara T, Kashihara D, Ichimura A, Kimura I, Tsujimoto G, Hirasawa A. Role of free fatty acid receptors in the regulation of energy metabolism. Biochim Biophys Acta. 2014;1841(9):1292-300.

39. Akbar H, Grala TM, Vailati Riboni M, Cardoso FC, Verkerk G, McGowan J, et al. Body condition score at calving affects systemic and hepatic transcriptome indicators of inflammation and nutrient metabolism in grazing dairy cows. J Dairy Sci. 2015;98(2):1019-32.

40. Gotoh $\mathrm{C}$, Hong YH, Iga T, Hishikawa D, Suzuki Y, Song SH, et al. The regulation of adipogenesis through GPR120. Biochem Biophys Res Commun. 2007;354(2):591-7.

41. Ichimura A, Hirasawa A, Poulain-Godefroy O, Bonnefond A, Hara T, Yengo L, et al. Dysfunction of lipid sensor GPR120 leads to obesity in both mouse and human. Nature. 2012;483(7389):350-4.

42. Bell AW, Bauman DE. Adaptations of glucose metabolism during pregnancy and lactation. J Mammary Gland Biol Neoplasia. 1997:2(3):265-78.

43. Contreras GA, Sordillo LM. Lipid mobilization and inflammatory responses during the transition period of dairy cows. Comp Immunol Microbiol Infect Dis. 2011;34(3):281-9.

44. Oh DY, Talukdar S, Bae EJ, Imamura T, Morinaga H, Fan W, et al. GPR120 is an omega-3 fatty acid receptor mediating potent anti-inflammatory and insulin-sensitizing effects. Cell. 2010;142(5):687-98.

45. Tunaru S, Kero J, Schaub A, Wufka C, Blaukat A, Pfeffer K, et al. PUMA-G and HM74 are receptors for nicotinic acid and mediate its anti-lipolytic effect. Nat Med. 2003;9(3):352-5.

46. Kamanna VS, Kashyap ML. Nicotinic acid (niacin) receptor agonists: will they be useful therapeutic agents? Am J Cardiol. 2007;100(11 A):S53-61.

47. Holm C. Molecular mechanisms regulating hormone-sensitive lipase and lipolysis. Biochem Soc Trans. 2003;31(Pt 6):1120-4.

48. Edfalk S, Steneberg P, Edlund H. Gpr40 is expressed in enteroendocrine cells and mediates free fatty acid stimulation of incretin secretion. Diabetes. 2008;57(9):2280-7.

49. Hirasawa A, Tsumaya K, Awaji T, Katsuma S, Adachi T, Yamada M, et al. Free fatty acids regulate gut incretin glucagon-like peptide-1 secretion through GPR120. Nat Med. 2005:11(1):90-4.

50. Raptis DA, Limani P, Jang JH, Ungethum U, Tschuor C, Graf R, et al. GPR120 on Kupffer cells mediates hepatoprotective effects of omega3-fatty acids. J Hepatol. 2014;60(3):625-32

51. Steneberg P, Rubins N, Bartoov-Shifman R, Walker MD, Edlund H. The FFA receptor GPR40 links hyperinsulinemia, hepatic steatosis, and impaired glucose homeostasis in mouse. Cell Metab. 2005;1(4):245-58.

52. Nakamura MT, Yudell BE, Loor JJ. Regulation of energy metabolism by longchain fatty acids. Prog Lipid Res. 2014:53:124-44.

53. Manosalva C, Mena J, Velasquez Z, Colenso CK, Brauchi S, Burgos RA, et al. Cloning, identification and functional characterization of bovine free fatty acid receptor-1 (FFAR1/GPR40) in neutrophils. PLoS One. 2015;10(3):e0119715.

54. Goff JP, Horst RL. Physiological changes at parturition and their relationship to metabolic disorders. J Dairy Sci. 1997;80(7):1260-8.

55. Hoeben D, Monfardini E, Opsomer G, Burvenich C, Dosogne H, De Kruif A et al. Chemiluminescence of bovine polymorphonuclear leucocytes during the periparturient period and relation with metabolic markers and bovine pregnancy-associated glycoprotein. J Dairy Res. 2000;67(2):249-59.

56. Kehrli Jr ME, Nonnecke BJ, Roth JA. Alterations in bovine neutrophil function during the periparturient period. Am J Vet Res. 1989;50(2):207-14.

57. Grimble RF. Nutrition and cytokine action. Nutr Res Rev. 1990:3(1):193-210.

58. Piepers S, De Vliegher S. Oral supplementation of medium-chain fatty acids during the dry period supports the neutrophil viability of peripartum dairy cows. J Dairy Res. 2013;80(3):309-18. 
59. Van Oostveldt K, Paape MJ, Dosogne H, Burvenich C. Effect of apoptosis on phagocytosis, respiratory burst and CD18 adhesion receptor expression of bovine neutrophils. Domest Anim Endocrinol. 2002;22(1):37-50.

60. Kostylina G, Simon D, Fey MF, Yousefi S, Simon HU. Neutrophil apoptosis mediated by nicotinic acid receptors (GPR109A). Cell Death Differ. 2008;15(1):134-42.

61. Savill J, Haslett C. Granulocyte clearance by apoptosis in the resolution of inflammation. Semin Cell Biol. 1995;6(6):385-93.

62. Tak T, Tesselaar K, Pillay J, Borghans JA, Koenderman L. What's your age again? Determination of human neutrophil half-lives revisited. J Leukoc Biol. 2013;94(4):595-601.

63. Minor DJ, Trower SL, Strang BD, Shaver RD, Grummer RR. Effects of nonfiber carbohydrate and niacin on periparturient metabolic status and lactation of dairy cows. J Dairy Sci. 1998:81(1):189-200.

64. Morey SD, Mamedova LK, Anderson DE, Armendariz CK, Titgemeyer EC, Bradford BJ. Effects of encapsulated niacin on metabolism and production of periparturient dairy cows. J Dairy Sci. 2011;94(10):5090-104.

65. Yuan K, Shaver RD, Bertics SJ, Espineira M, Grummer RR. Effect of rumenprotected niacin on lipid metabolism, oxidative stress, and performance of transition dairy cows. J Dairy Sci. 2012;95(5):2673-9.

66. Liou AP, Lu X, Sei Y, Zhao X, Pechhold S, Carrero RJ, et al. The G-proteincoupled receptor GPR40 directly mediates long-chain fatty acid-induced secretion of cholecystokinin. Gastroenterology. 2011;140(3):903-12.

67. Li X, Yu Y, Funk CD. Cyclooxygenase-2 induction in macrophages is modulated by docosahexaenoic acid via interactions with free fatty acid receptor 4 (FFA4). FASEB J. 2013;27(12):4987-97.

68. Suckow AT, Polidori D, Yan W, Chon S, Ma JY, Leonard J, et al. Alteration of the glucagon axis in GPR120 (FFAR4) knockout mice: a role for GPR120 in glucagon secretion. J Biol Chem. 2014;289(22):15751-63.

69. Suzuki M, Takaishi S, Nagasaki M, Onozawa Y, lino I, Maeda H, et al. Medium-chain fatty acid-sensing receptor, GPR84, is a proinflammatory receptor. J Biol Chem. 2013;288(15):10684-91.

70. Wang J, Wu X, Simonavicius N, Tian H, Ling L. Medium-chain fatty acids as ligands for orphan $\mathrm{G}$ protein-coupled receptor GPR84. J Biol Chem. 2006;281(45):34457-64

71. Chen L, So WY, Li SY, Cheng Q, Boucher BJ, Leung PS. Niacin-induced hyperglycemia is partially mediated via niacin receptor GPR109a in pancreatic islets. Mol Cell Endocrinol. 2015;404:56-66.

72. Elangovan S, Pathania R, Ramachandran S, Ananth S, Padia RN, Lan L, et al. The niacin/butyrate receptor GPR109A suppresses mammary tumorigenesis by inhibiting cell survival. Cancer Res. 2014;74(4):1166-78.

73. Li HM, Zhang M, Xu ST, Li DZ, Zhu LY, Peng SW, et al. Nicotinic acid inhibits glucose-stimulated insulin secretion via the $G$ protein-coupled receptor PUMA-G in murine islet beta cells. Pancreas. 2011:40(4):615-21.

\section{Submit your next manuscript to BioMed Central and we will help you at every step:}

- We accept pre-submission inquiries

- Our selector tool helps you to find the most relevant journal

- We provide round the clock customer support

- Convenient online submission

- Thorough peer review

- Inclusion in PubMed and all major indexing services

- Maximum visibility for your research

Submit your manuscript at www.biomedcentral.com/submit

C Biomed Central 